\title{
Los chiles que le dan sabor al mundo
}

The chilies that give flavor to the world.

\section{María Soledad Celaya Mijangos ${ }^{\mathrm{a}}$, Edú Ortega Ibarra $^{b}$}

\begin{abstract}
:
This literary work encompasses various aspects of chili and the elements that make it become food heritage, highlighting that its popular consumption goes beyond flavor, encompassing cultural, historical, gastronomic, biological and emotional aspects. It allows people and strangers to marvel at the great diversity of chili peppers in Mexico, explaining through their chapters, which have been written by 21 authors, therefore, expresses versatility of opinion and at the same time union of ideas about this condiment.
\end{abstract}

Keywords:

Chili, Mexico, food, diversity

Resumen:

Esta obra literaria engloba diversos aspectos sobre el chile y los elementos que lo hacen convertirse en patrimonio alimentario, destacando que su popular consumo va más allá del sabor, englobando aspectos culturales, históricos, gastronómicos, biológicos y emocionales. Permite maravillar a propios y a extraños con la gran diversidad de chiles en México, explicando a través de sus capítulos, lo cuales han sido escritos por 21 autores, por lo tanto, expresa versatilidad de opinión y la vez unión de ideas acerca de este condimento.

Palabras Clave:

Chile, México, alimento, diversidad

\section{Introducción}

El chile es un símbolo del mexicano en todo el mundo, es utilizado para la preparación de guisados, platillos y una gran diversidad de salsas. El uso de este condimento surge desde la época preclásica donde era utilizado para la alimentación, como ofrenda en rituales e incluso en relatos mitológicos. México es un país biocultural derivado de las costumbres, técnicas y otros aspectos que conforman la identidad de cada estado que lo conforman. El chile es consumido por su sabor y versatilidad, pero también por su representación simbólica y emocional. Son utilizados para la preparación de platillas para celebrar la más alegre fiesta y para realizar la salsa de los tamales para un velorio, también como medicina según las creencias y rituales de cada lugar.

El chile (Capsicum) es originario del continente americano, posteriormente fue distribuido debido a la llegada de los europeos, actualmente es cultivado en todo el mundo. Existe una gran diversidad de chiles, en México más de 160 mil hectáreas están dedicadas a su cultivo, destacando el chile jalapeño, serrano, ancho y guajillo. El

\footnotetext{
a Universidad del Istmo. https://orcid.org/0000-0002-8021-6455, Email: nutmscm2218@ gmail.com

b Autor de Correspondencia, Universidad del Istmo, https://orcid.org/0000-0002-6504-7366, Email: eduortegaibarra@ gmail.com
} 
incremento en la siembra de este alimento, ha llevado a la comunidad científica a desarrollar un mejoramiento, a través del uso de herramientas biotecnológicas, genéticas y tradicionales, con el objetivo de realizar cultivos resistentes a plagas y mayor rendimiento. El género Capsicum presenta 35 especies, de las cuales en México se encuentran cuatro, divididos en razas por ello es considerado el centro de origen y diversidad del chile.

La producción del chile se deriva de dos sistemas de cultivo: el de gran escala lo caracteriza la utilización de semillas comerciales y la utilización de tecnología agrícola moderna, en cambio el cultivo a pequeña escala es a través de la siembra de semillas locales y técnicas tradicionales de cada región. Estos cultivos se enfrentan a la erosión genética que consiste en la disminución de diversidad en algunos cultivos, esto se debe a que los agricultores ante la demanda de su producto deben recurrir a maquinaria, agroquímicos y fertilizantes, para ello es necesario que las plantas de chile sean uniformes, provocando la siembra de plantas resistentes dejando de cultivar otras variedades. Por ejemplo: el chile huacle en Oaxaca con el pasar el tiempo ha disminuida su siembra y en Coahuila el chile ancho ya no se cultiva. Ante esta situación se han implementado programas de conservación de variedades criollas, el banco de semillas y diversos trabajos científicos en busca de la preservación de la diversidad.

El chile es un símbolo alimentario de los pueblos indígenas que se ha hecho presente desde hace muchos años atrás, esto se ha demostrado de acuerdo a varios estudios realizado en la zona sur del país a través de la identificación química del chile en vasijas cerámicas utilizadas en el periodo preclásico. El chile está presente en toda la cultura mexicana, pero adquiere rasgos distintos en cada región. En Guerrero en estado de Acatepec, a las autoridades municipales se les da de comer un caldo sumamente picoso de chiles llamados chiltepín o piquín provocando dolor y ardor este ritual es utilizado como penitencia. En Oaxaca este tipo de chile es utilizado para la protección contra las envidias y enojos.

En la región de la Mixteca el chile se consume verde, seco, cocido y crudo, es utilizado en una gran variedad de platillos típicos (moles, salsas y guisados). En la región del istmo, el uso del chile shigundo es muy popular, este pequeño chile es normalmente encontrado en los cultivos de maíz, en los jardines y en los caminos hacía los terrenos de cultivo, se une a diferentes ingredientes al gusto para dar como resultado salsas que caracterizan el sabor de la comida istmeña.

A lo largo de sus capítulos el libro "los chiles que le dan sabor al mundo", te envuelve de conocimientos acerca del chile sus orígenes, especies y características generales y específicas que permiten contextualizarte y lograr una comprensión inicial para poder abordar el resto del libro. Al hablar del chile como símbolo de mexicanidad, los autores aportan una amplia gama de estudios científicos acerca de las diversas culturas de nuestro país y la importancia de este alimento entre ellas y no solo como condimento, también como protección espiritual.

Además de sustento científico, los autores relatan sus experiencias de acuerdo a su lugar de origen o el lugar en donde desarrollaron sus trabajos de investigación. En lo particular me identifiqué con el espacio del libro dedicado a hablar sobre la comida istmeña, la autora relata de acuerdo a su experiencia el uso del chile en la gastronomía, da a conocer los platillos típicos de una forma muy agradable, permite recordad los sabores y olores característicos de la cocina tradicional.

Considero que el libro maneja un lenguaje y una secuencia que permite la conexión y el entendimiento del tema, además enaltece la cultura de México, contiene relatos en lenguas originarias de los pueblos indígenas, historias populares, rituales, fotografías y recetas de diversos platillos, con el propósito de proporcionar recursos al lector para poder comprender lo que los autores quieren expresar. Hablar del chile sobre todo para cultura mexicana es un signo de identidad, pero también de suma importancia para múltiples estudios científicos de cualquier rama, por lo tanto, este libro permite visualizar los avances en su investigación y los posibles temas para trabajos futuros.

\section{Conclusión}

La investigación sobre alimentos mexicanos es una importante contribución y permite resaltar el valor nutricional, cultural y emocional del Capsicum, esta obra es el reflejo del esfuerzo de doctores, cocineros, investigadores, arqueólogos, antropólogos, biólogos y ecologistas. La investigación es una fuente importante de reflexión y conocimiento, la reseña de este libro permite visualizar de manera general el contenido de esta obra e introducir al lector.

\section{Referencias}

[1] Aguilar-Meléndez, A., Vásquez, M. A., Katz, E., \& Colorado, M. R. H. (2018). Los chiles que le dan sabor al mundo. Madrid, España: Alianza Editorial. 318 páginas. ISBN: 9786075026992 